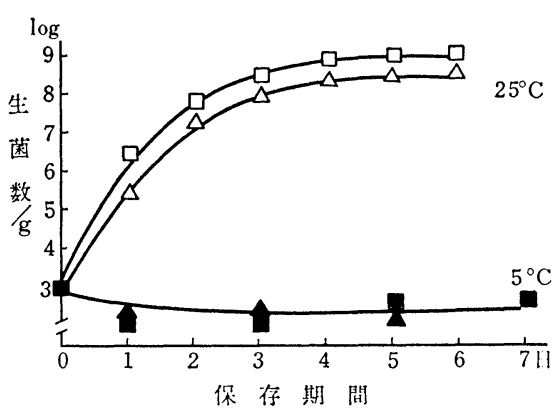

第 3 図 タルタルソース中での $S$. nagoya の $K$. oxytoca の消長 (再現実験)

ネギ $30 \mathrm{~g}$, マヨネーズ $15 \mathrm{~g}$, その他パセリ, 人参, 八ム/ 1 人前. $\mathrm{pH}$ 4.5) で，原因物質は， S. nagoya と $K$. oxytoca の混合感染による集団食中毒と判定された．原 因食品の一般細菌学的品質は，第 2 図に示すように大腸

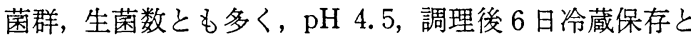
いら条件にもかかわらず, S. nagoya $10^{2} / \mathrm{g}, K$. oxytoca $10^{3} / \mathrm{g}$ の菌量を検出した.

3. タルタルソース中での原因菌の生存態度
サラダ等の酸性食品中での細菌の消長は, $\mathrm{pH} 4.0$ 以 下では漸減もしくは，死隇すると言われているが，原因 食「タルタルソース」中での原因細菌は生残しており， 第 3 図に示すように, 再現実験においても低温保存下で 漸减を認めず， $25^{\circ}$ では急速に增殖をみた。

4. 考 察

以上の結果から，高濃度に污染した「タルタルソー ス」を 1 人約 $80 \mathrm{~g}$ 摂食 (推定摂取菌量 S. nagoya $8 \times$ $10^{4}, K$. oxytoca $\left.2.5 \times 10^{5}\right)$ による両菌の混合感染事例と 考えた. K. oxytoca については, 一次的腸炎起病性は明 らかではないが，今回，発症期間が長く発症ピークが二 つあり，さらに原因食品，患者からS. nagoya と同時に 相当菌量の検出をみたことから十分に何らかの関与をし たものと考えられる．原因食への污染・増殖については 明らかにできなかったが, 調理過程で使用器具, 原材料 などから相当高濃度の污染があったものと考光られる。 なお，後日卵を納入した鶏舎について調查を実施したが 本菌による污染を証明するには至らなかった。

（広島県衛生研究所 小川博美, 岸本敬之, 得 能弘志，佐々木実己子, 福田伸治：広島県可 部保健所 松永治稔, 小谷庄吾, 長谷川俊治, 畑本典昭，杉村光永）

\title{
仕出し弁当によるウェルシュ菌食中毒
}

\section{1. 事件発生の概要}

発生年月日 昭和57年 6 月 2 日

発 生 場 所 福井県大飯郡高浜町田ノ浦 $\mathrm{K}$ 電力 (株) 原 子力発電所構内, 同作業員宿舎

摂食者数 1,004 名

患者 数 205 名

原因食品 鯨の魚煮

病因物 質 耐熱性ウェルシュ菌

\section{2. 事件の探知}

昭和 57 年 6 月 2 日, 社会保健高浜病院より保健所に高 浜原電作業員数名が食中毒症状を訴兄来院, 患者はさら に増える模样との届出があった.

\section{3. 患者発生状況及び原因食品}

本食中毒は $\mathrm{K}$ 本舗高浜営業所 $\mathrm{M}$ 寮で調製された 6 月 1 日の昼食仕出し弁当（1,063 食）を摄食した者の中から のみ発生した．患者数は 205 名で，発症率は $20.4 \%$ で あった. 潜伏時間は 6〜22 時間, 平均 13 時間 20 分で, 主症状は下痢，腹痛であった。下痢回数は 4 5 回のも のが多く，ほとんどは軽症であったが脱水症状の激しい 16名は入院した．保健所で調查可能であった 1,004 食に

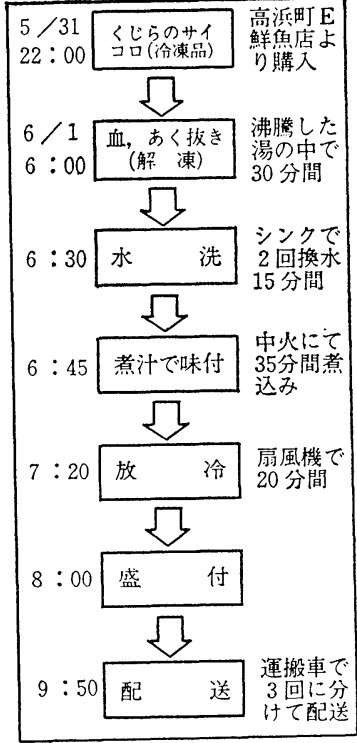

第 1 図 鯨の角惹の調理方法 
第 1 表 食品検查成績

\begin{tabular}{|c|c|c|c|c|c|}
\hline & 品 & $\mathrm{SPC} / \mathrm{g}$ & 大腸菌群 & ウ菌/g & 要 \\
\hline $\begin{array}{c}6 \text { 月 } 1 \text { 日 } \\
\text { 昼食弁当 } \\
\text { (検食) }\end{array}$ & $\begin{array}{l}\text { ブリしょうが 焼 } \\
\text { 鯨 の 角 惹 } \\
\text { ウインナー卵ロール }\end{array}$ & $\begin{array}{l}1.3 \times 10^{5} \\
100> \\
2.3 \times 10^{7}\end{array}$ & $\begin{array}{l}(+) \\
(+) \\
(+)\end{array}$ & $\begin{array}{c}(-) \\
1.1 \times 10^{6} \\
(-)\end{array}$ & $\mathrm{A}$ 型ウ菌 Hobbs 3 型 \\
\hline $\begin{array}{l}6 \text { 月 } 1 \text { 日 } \\
\text { 昼食弁当 } \\
\text { (末撰食分) }\end{array}$ & 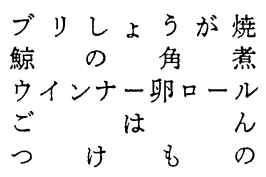 & $\begin{array}{l}5.0 \times 10^{8} \\
100> \\
3.0 \times 10^{7} \\
1.7 \times 10^{8} \\
5.0 \times 10^{8}\end{array}$ & $\begin{array}{l}(+) \\
(+) \\
(+) \\
(+) \\
(+)\end{array}$ & $\begin{array}{c}(-) \\
2.5 \times 10^{7} \\
(-) \\
(-) \\
(-)\end{array}$ & $\mathrm{A}$ 型ウ菌 Hobbs 3 型 \\
\hline $\begin{array}{l}\text { 原r料 } \\
\text { (冷凍品) }\end{array}$ & $\begin{array}{l}\text { 鯨 } \\
\text { ウインナー肉 }\end{array}$ & $\begin{array}{l}4.5 \times 10^{8} \\
100>\end{array}$ & $\begin{array}{l}(+) \\
(-)\end{array}$ & $\begin{array}{r}\text { 増菌 }(+) \\
(-)\end{array}$ & Hobbs 型 ut. \\
\hline
\end{tabular}

ついて食品別 $\chi^{2}$ 検定を行ったところ，1\%の危険率で くじらの角煮とウインナー卵ロールが有意と認められ た. しかし, 後述のとおり鯨の角煮から患者由来株と同 タイプのウェルシュ菌が検出されたので, 解の角煮が原 因と決定した. 調理方法, 配送方法は調理担当者の聴取 によると第 1 図のとおりであった. すなわち，6月 1 日 午前 6 時, 原料冷凍鯨肉 $25 \mathrm{~kg}(5 \mathrm{~kg}$ 角 $\times 5)$ を沸とう 水中で30分間ボイル（保健所の再現実験では湯温 $100^{\circ}$ は正味10分間), 水道水で 15 分間水洗した後, $1.5 \mathrm{~cm}$ 角に切り $21 \mathrm{~L}$ の煮汁の中で 35 分間味付を行った（同, 煮汁 $100^{\circ}$ は正味 25 分). このあと径 $45 \mathrm{~cm}$ のボール 及びバットに平に入れ扇風機で20分間放冷した（同，鯨 の角煮は $77^{\circ}$ から $27^{\circ}$ に下がる). 盛付は 8 時頃より行 い11時頃完了した. この間盛付の終ったものはご飯と二 段に重ねて 9 時50分頃より 3 回に分けて配送した. 配送 された弁当は作業員詰所に昼食時まで放置された。

\section{4. 細菌学的検索}

\section{1）原因食品からの菌検索}

6 月 1 日の昼食弁当 (検食), 同未摂取弁当残品及び 原料について病原菌検索を行い, 第 1 表のように鯨の角 煮から Hobbs 3 型の耐熱性ウェルシュ菌を検出した. 原料肉より分離した耐熱性ウェルシュ菌はHobbs 型血 清に凝集しなかった. 鯨の角煮中の菌数は $1.1 \times 10^{6} / \mathrm{g}$ 及び $2.5 \times 10^{7} / \mathrm{g}$ であった。

\section{2) ふん便からの菌検索}

患者及び従業員のふん便検査の結果, 患者 3 名中 3 名
からくじらの角煮と同様 Hobbs 3 型の耐熱性ウェルシ 二菌を検出した. 従業員 5 名から分離したウェルシュ菌 は Hobbs 型に合致しなかった. 患者便中のウェルシュ 菌数は $4.0 \times 10^{5} / \mathrm{g} \sim 9.2 \times 10^{6} / \mathrm{g}$ であった.

食品及び患者便から原因と推定される他の食中毒起因 菌は検出されなかった。.

\section{3）エンテロトキシンの検出}

RPLA 法 (デンカ製品による) によって患者便から直 接エンテロトキシンの検出を試みた結果, 被験者 3 名全 員の便にエンテロトキシンを検出できた. また患者由来 株, 鯨の角煮由来株が Duncan \& Strong 培地でェンテ ロトキシンを産生した. 卸元在庫の原料鯨肉から分離し た耐熱性ウェルシュ菌は, 同上培地でトキシンを産生し なかった。

\section{5. とめ}

本食中毒は原料鯨肉を污染していたウェルシュ菌芽胞 が調理後も生き残り, 発芽, 増殖した結果発生したもの と思われる. 調理方法が事情聴取のとおり行われたもの と考えると, 調理後, 摂食までの 4 時間半に食中毒発症 菌量に到った理由は明確ではない.しかし調理場面積 $90 \mathrm{~m}^{2}$ で, 寮生 120 名, 昼食弁当 400 食で営業開始しな がら, 増設工事にともなう急激な作業員増加による, 能 力を越えた無理な注文（1,000 食以上）を受けた結果, 調理, 搬送全般に無理が生じ今回の中毒を招いたものと 考えられる.

(福井県衛生研究所 小林桂子) 